\title{
STEM CELLS AND CORNEAL EPITHELIAL REGENERATION
}

\author{
FRIEDRICH E. KRUSE \\ Heidelberg, Germany
}

\begin{abstract}
SUMMARY
Self-renewing tissues such as the corneal epithelium contain stem cells which represent the proliferative reserve. Studies of cellular differentiation and proliferation suggest that corneal epithelial stem cells are localised exclusively in the basal limbal epithelium. Although regulatory factors for the amplification of corneal stem cells are unknown, serum factors such as retinoic acid might induce differentiation of stem cells to transient amplifying cells which are responsible for cell amplification. These cells are regulated by various polypeptide growth factors and extracellular calcium. Loss or malfunction of stem cells does not permit maintenance or regeneration of the corneal epithelial mass but leads to conjunctivalisation of the corneal surface. Clinically, several ocular surface disorders such as chemical burns can cause limbal damage and consecutive limbal insufficiency. Treatment for these disorders is available only by transplantation of healthy stem cells, which can be performed as both autograft and allograft.
\end{abstract}

\section{PRINCIPLES OF CORNEAL EPITHELIAL REGENERATION}

Corneal epithelium is subject to a constant process of cell renewal and regeneration. Cells in the uppermost layer of the corneal epithelium are continuously desquamated from the surface and must be replaced by cell proliferation. The exclusive localisation of dividing cells in the basal layer of the corneal epithelium suggests that proliferation is limited to basal cells. ${ }^{1-4}$ Only cells which are in contact with the basement membrane have the ability for mitotic cell division while cells which are displaced into the suprabasal layers become post-mitotic and lose their capability for cell division. ${ }^{5}$

The kinetics of the maintenance of the corneal epithelial mass is characterised by a vertical as well as a horizontal

Correspondence to; Dr med. Friedrich Eduard Kruse, Augenklinik der Universität Heidelberg, Im Neuenheimer Feld 400, D-69120 Heidelberg, Germany. movement of cells. The vertical movement can be documented experimentally by the chase of previously labelled basal cells and might be due to the proliferative pressure in the basal cell layer. ${ }^{5}$ The horizontal movement of corneal epithelial cells from the periphery to the centre was observed after experimental corneal epithelial wounding. ${ }^{6.7}$ Similarly in rabbits, the centripetal replacement of corneal epithelium after corneal grafts which originates in the donor epithelium has been shown to start in the periphery of the graft. ${ }^{8}$ Tracing of peripherally located ink particles in the murine epithelium has proved that the centripetal movement of corneal epithelial cells also takes place under physiological circumstances in normal animal corneas. ${ }^{9}$ Several observations indicate that the centripetal movement exists in human corneas as well. First, corneal erosions which do not include the limbal epithelium heal in a centripetal fashion. ${ }^{10}$ Second, small subepithelial cysts which develop between the sutures of corneal grafts move towards the centre when the sutures are removed. ${ }^{11}$ Third, a centripetal movement of epithelial cells under physiological conditions was observed by specular microscopy. ${ }^{12}$

The proliferation of basal cells as well as horizontal and vertical cell movements have been summarised in kinetic models which describe the maintenance of the corneal epithelial mass. ${ }^{13.14}$ While these mechanisms of the maintenance of corneal epithelium are generally accepted, the question of the origin of corneal epithelial cell proliferation has sparked a considerable controversy. Two opposing theories exist, one of which claims that the origin of corneal epithelium is derived from the adjacent conjunctiva by conjunctival transdifferentiation while the other claims that the origin of corneal epithelial proliferation depends on corneal stem cells in the limbal basal epithelium.

\section{CONJUNCTIVAL TRANSDIFFERENTIATION}

The first theory is based on early studies of corneal wound 
healing in humans which observed an ingrowth of conjunctival epithelium onto the denuded cornea following large epithelial wounds extending beyond the limbus. ${ }^{15.16}$ Further observations and experimental studies showed that in the absence of vascular ingrowth conjunctival epithelium on the corneal surface loses its conjunctival phenotype and becomes cornea-like. ${ }^{16-18}$ This transformation of conjunctival epithelium to a corneal epithelium was described by the term 'conjunctival transdifferentiation'. This phenomenon was investigated in numerous animal studies ${ }^{19-22}$ and led to the assumption that normal corneal epithelium is maintained by the surrounding conjunctival epithelium. ${ }^{13}$

However, two lines of evidence have cast doubt upon the existence of true conjunctival transdifferentiation. First, the histological and ultrastructural appearance of transdifferentiated conjunctival epithelium differs from that of genuine corneal epithelium, for example with respect to the presence of goblet cells. ${ }^{23}$ Second, the phenotype of the epithelium after transdifferentiation shows distinct differences from the phenotype of genuine corneal epithelium with respect to its metabolism as well as its composition of proteins and keratins. ${ }^{2+26}$ These data indicate that conjunctival transdifferentiation does not represent the true conversion of a differentiated conjunctival phenotype into a differentiated corneal phenotype but rather describes an environmental modulation of the conjunctival epithelium. This notion is supported by the observation that conjunctival transdifferentiation can be inhibited by vascularisation. ${ }^{16.17}$ In contrast, occlusion of the vessels in conjunctivalised epithelium induces conjunctival transdifferentiation. ${ }^{27}$

These observations suggest that the blood vessels supply conjunctival epithelium on the corneal surface with substances which prevent transdifferentiation or which are - in other words - important for the maintenance of the conjunctival phenotype. Numerous studies by, for example, Tseng and coworkers have demonstrated that retinoic acid is of great importance for the differentiation of goblet cells under physiological conditions and that retinoic acid can prevent conjunctival transdifferentiation. ${ }^{28-31}$ It is therefore tempting to speculate that a localised deficiency of retinoic acid (and other unidentified factors) results in a loss of goblet cells and a modulation of conjunctival epithelium into a cornea-like epithelium.

A closer analysis of the experiments which were performed to induce conjunctival transdifferentiation suggest another explanation for transdifferentiation in addition to environmental modulation. The vast majority of the experiments investigating transdifferentiation used a model in which chemical and mechanical removal of corneal and limbal epithelium causes the conjunctival epithelium to move onto the cornea. ${ }^{32}$ These experiments, however, resulted in great variability concerning the incidence of the resulting transdifferentiation. Application of a chemical agent (n-heptanol) for a short period caused transdifferentiation in $86 \%$ of the treated eyes while longer exposure to $\mathrm{n}$-heptanol in combination with mechanical scraping led to transdifferentiation in only $32 \%$ of the eyes. ${ }^{20-27}$ In the remaining eyes conjunctival epithelium did not transdifferentiate but was supported by neovascularisation. These findings suggest that the extent of removal of the corneal epithelium is responsible for the incidence of transdifferentiation or persistent conjunctivalisation. This observation draws attention to the role of limbal epithelium in the maintenance and restoration of corneal epithelium. It is tempting to speculate that complete removal of both corneal and limbal epithelium induces irreversible conjunctivalisation. On the contrary, incomplete removal of the limbal epithelium may allow the reconstruction of the original epithelium after a certain period which is needed for recovery of the damaged epithelium and which can falsely be interpreted as the time sequence of conjunctival transdifferentiation.

To prove this hypothesis we investigated the interaction between the duration of corneal exposure to $n$-heptanol and the extent of corneal and limbal epithelial removal by means of a histological survey. ${ }^{33}$ The results indicate that exposure of the corneal epithelium to $n$-heptanol with mechanical scraping results in complete removal of the epithelium when the agent is applied for more than 60 seconds. In contrast, the limbal epithelium was much more resistant to this treatment. Exposure of the limbal epithelium to $n$-heptanol resulted in incomplete removal of the basal layer even when the duration of treatment was extended to 180 seconds. These results indicate that the treatment used in the aforementioned investigations to remove the corneal epithelium completely (n-heptanol treatment of less than 120 seconds) most probably also resulted in incomplete removal of the limbal basal epithelium.

To investigate further whether the remaining basal limbal epithelium retained its proliferative capacity despite the treatment we conducted tissue cultures of corneoscleral specimens from eyes which had been treated with n-heptanol for 60 and 90 seconds following mechanical scraping of the epithelium. ${ }^{33}$ In these cultures we observed a continuous outgrowth from the limbal epithelium onto the denuded stroma. Immunohistochemical staining with various antibodies showed that the outgrowth was of limbal derivation. These results indicate that the remaining basal epithelium retains its proliferative capacity and therefore can reconstitute an epithelial phenotype after removal of the corneal epithelium as observed in the aforementioned transdifferentiation experiments. In the light of these results experimentally induced transdifferentiation could be explained by the following sequence: First, removal of the epithelium by n-heptanol leads to incomplete removal of the basal limbal epithelium. Second, conjunctival epithelium overgrows the limbal basal epithelium and leads to conjunctivalisation of the corneal epithelium. Third, the remaining limbal epithelium recovers and replaces the conjunctival epithelium with corneal epithelium which appears as conjunctival transdifferentiation. These findings highlight the role of the basal limbal 
epithelium for the maintenance of the corneal epithelial mass under physiological conditions and its importance for corneal regeneration after epithelial defects. This leads to the second theory regarding the origin of the corneal epithelium which claims that the origin of the corneal epithelium lies in corneal stem cells located in the limbal basal epithelium.

Davanger and Evansen ${ }^{34}$ were the first to speculate that corneal epithelium derives from the limbal pallisades of Vogt. This hypothesis was based on the observation that pigmented epithelial migration lines which occur in heavily pigmented eyes migrate from the limbus towards the centre of the cornea. Ten years later Schermer et al. ${ }^{35}$ conducted a survey of the cellular differentiation of corneal and limbal epithelium with respect to a certain class of intermediate filaments, i.e. keratins. The most important conclusion of this study was the hypothesis that corneal epithelium originates from the limbus and more precisely that the limbal basal epithelium contains the stem cells of the corneal epithelium.

\section{EPITHELIAL STEM CELLS}

The presence of stem cells is postulated in all self-renewing tissues, where they serve as the reserve for cell renewal and cell proliferation. ${ }^{36-38}$ Epithelial stem cells share the following characteristics which have also been postulated for the stem cells of the corneal epithelium: ${ }^{39,40}$ First, stem cells have a long life span which might be equivalent to the life of the organism which harbours them. Second, they have an almost unlimited potential for (cologogenic) cell division. Third, stem cells are slow cycling, which indicates a low mitotic activity. Fourth, stem cells are the least differentiated cells in the tissue and lack markers which indicate greater differentiation. Fifth, stem cells can be induced on demand, by certain factors to differentiate into transient amplifying cells. In contrast to stem cells transient amplifying cells are characterised by a high mitotic rate but a limited proliferative capacity. At a higher level of differentiation than stem cells, transient amplifying cells embark on a pathway leading to further differentiation and ultimately to cell death. After a high but limited number of cell divisions transient amplifying cells further differentiate to post-mitotic cells which have lost the capacity for cell division. These post-mitotic cells then become terminally differentiated and die after a certain time.

In contrast to haematopoietic stem cells, which have been positively identified by antibodies, ${ }^{41}$ the existence of stem cells has not been positively proven in any of the remaining self-renewing tissues such as the epithelium of the skin or the ocular surface. However, a wide body of indirect evidence suggests the presence of stem cells in the corneal epithelium as well.

\section{LOCATION OF CORNEAL EPITHELIAL STEM CELLS IN THE BASAL LIMBAL EPITHELIUM}

Evidence for the limbal location of corneal epithelial stem cells is based mainly on the observation that only the limbal basal epithelium contains cells which exhibit two of the aforementioned characteristics of stem cells. First, the limbal basal epithelium contains the least differentiated cells of the corneal epithelium. Second, the limbal basal epithelium contains cells which exhibit the proliferative characteristics of stem cells.

\section{The Basal Limbal Epithelium Contains the Least Differentiated Cells of the Corneal Epithelium}

The differential expression of keratins first allowed the separation of cell populations within the corneal epithelium according to their level of differentiation. Keratins are intermediate-type filaments which naturally occur as pairs consisting of an acidic keratin with its matching basic keratin. Among the more than 20 keratins which have been classified according to their isoelectric focussing point by Moll and coworkers, ${ }^{+2}$ some indicate a high level of differentiation while others are found mostly in less differentiated cells. ${ }^{+2,43}$

The development of specific antibodies by Sun and coworkers $^{35.44 .45}$ first allowed identification of the location of the $64 \mathrm{kDa}$ keratin $\mathrm{K} 3$ which indicates a cornea-specific type of differentiation. It was observed that keratin K3 exists in the suprabasal epithelium of the limbus and the entire corneal epithelium but is expressed in neither the limbal basal epithelium nor the adjacent bulbar conjunctiva. This observation led to the hypothesis that the limbal basal epithelium lacks a differentiated cornea-type phenotype and therefore contains the least differentiated cells of the epithelium, i.e. stem cells. ${ }^{35}$ Further studies have shown that the basal limbal epithelium also lacks the expression of the second half of the corneal-specific keratin, pair, i.e. K12, which is expressed in the suprabasal limbal epithelium and in the entire corneal epithelium. ${ }^{46.47}$ In summary these findings suggest that the basal limbal epithelium is less differentiated than the suprabasal limbal epithelium and the entire corneal epithelium with respect to the expression of cornea-specific keratins.

Studies of the expression of other keratins which indicate a relatively undifferentiated phenotype show further evidence for the low level of differentiation of limbal basal epithelium. In humans keratin K19 can always be found in limbal basal epithelium and sometimes in the basal epithelium of the periphery. In contrast, the suprabasal limbal and corneal epithelium do not express this keratin in most cases. $^{48}$ Since K19 is expressed in the entire limbal and corneal epithelium of the human fetus its presence in the basal limbal epithelium of the adult might indicate embryogenetically young cells, i.e. stem cells. On the contrary, K19-positive cells in the peripheral corneal epithelium might be the result of centripetal cell movement, since keratin K19 has also been associated with regenerating basal epithelium.

Recent studies of the co-expression of various classes of intermediate filaments haveidentified a subset of limbal and peripheral corneal basal cells which do not express keratin K3 but co-express keratin K19 and vimentin. ${ }^{49}$ 
Since this cell type was almost exclusively present in the basal epithelium of the superior limbal circumference, it was speculated that these cells might either represent a morphologically distinct subset of stem cells or migrating transient amplifying cells. ${ }^{49}$

Several attempts have been made to develop biochemical or immunological markers which are specific for limbal stem cells. Zieske and coworkers ${ }^{50}$ have generated a monoclonal antibody against a protein with the molecular weight of 50000 which is exclusively expressed in limbal basal epithelium. Although it was initially hoped that this protein represents a marker specific for limbal stem cells, further studies have shown that it represents the glycoloytic enzyme alpha-enolase which also occurs in other tissues. ${ }^{51}$ Its significance and function in limbal basal epithelial cells are currently being investigated.

All of the investigations described have identified the limbal basal epithelium as a group of cells with properties differing from the remaining corneal epithelium. However, these investigations were not able to differentiate between different subpopulations within the limbal basal epithelium. Nevertheless it is most likely that the limbal basal epithelium consists not only of stem cells but also of transient amplifying cells. An approach to differentiating between these cell populations within the limbal basal epithelium is by investigating their proliferative behaviour.

\section{The Basal Limbal Epithelium Contains Cells with the Proliferative Behaviour of Stem Cells}

Short-term labelling of cells with agents that identify mitotic divisions (such as tritiated thymidine, $\left[{ }^{3} \mathrm{H}\right] \mathrm{TdR}$ ) allows the identification of fast cycling transient amplifying cells whereas prolonged administration of the label enables the identification of slow cycling stem cells. ${ }^{52,53}$ Using these labelling characteristics Cotsarelis and coworkers ${ }^{54}$ were the first to differentiate between stem cells and transient amplifying cells in the basal limbal epithelium. After short-term labelling they observed proliferating cells in both the limbal and peripheral corneal basal epithelium, indicating the presence of transient amplifying cells. They then applied [3H]TdR for 14 days and extended the observation period to 4 weeks. Under these conditions only a very few labelled cells could be identified in the basal limbal epithelium (and none in the cornea). The authors interpreted this observation by suggesting that the cycling time of the limbal stem cells is longer than 2 weeks. ${ }^{54}$

In order to improve the chances of detecting stem cells, these quiescent progenitor cells can be exposed to substances which increase their level of differentiation and recruit them into a state of proliferation. Such agents which induce cellular differentiation are tumour promoters or antimetabolites. Topical application of the tumour promoter TPA (12-O-tetradecanoylphorbol-13-acetate) resulted in a preferential stimulation of the proliferation of limbal epithelial cells in comparison to corneal epithelial cells. ${ }^{54}$ However, not only the limbal but also the peripheral corneal epithelium showed a significant increase in the number of labelled cells after exposure to TPA. It therefore seems likely that not only limbal stem cells but early transient amplifying cells which are also present in corneal epithelium were stimulated by the tumour promoter.

In tissue cultures TPA has been used also to differentiate between stem and transient amplifying cells. Treatment of epithelial cell cultures with TPA induces terminal differentiation in the vast majority of the cells, which therefore stop proliferating. These cells represent transient amplifying cells. ${ }^{55-57}$ Only a fraction of the cultured cells can retain their undifferentiated phenotype and proliferate despite the presence of TPA. These TPA-resistant cells are the least differentiated cells in the epithelium, i.e. the stem cells. ${ }^{55-57}$

In order to prove further the existence of limbal stem cells on the basis of their response to TPA in tissue culture we used a serum-free clonal growth assay which allows the comparison of single cells of limbal and corneal epithelium. ${ }^{58}$ In this assay TPA-resistant colonies were observed in cultures not only from limbal but also from peripheral and central corneal epithelium. ${ }^{59}$ Both the absolute number of TPA-resistant colonies and the percentage of resistant colonies relative to the total number of colonies in control medium was significantly higher in cultures from limbal epithelium than from corneal epithelium. ${ }^{59}$ Although most TPA-resistant colonies were observed in cultures from limbal epithelium, the presence of TPAresistant colonies in corneal epithelial cultures as well does not seem to be consistent with the concept of the exclusive location of corneal epithelial stem cells in the limbus. It might however, be possible that TPA-resistant colonies derive not only from limbal stem cells but also from a second cell type which is present in both limbal and corneal epithelium, i.e. early transient amplifying cells. This interpretation is suggested by the observation that the pattern of differentiation and proliferative behaviour of TPA-resistant colonies in cultures from both limbal and corneal epithelium was almost identical. Furthermore, earlier studies showed that the tissue culture environment used in these studies promotes epithelial differentiation and that it is probably not possible to culture true stem cells on plastic substratum in serum-free medium. ${ }^{59}$ Taken together these findings suggest the existence of a pool of very early transient amplifying cells with stem cell characteristics (i.e. TPA resistance) in both limbal and corneal epithelium. The existence of such cells would also explain the clinical observation that the corneal epithelium can be maintained for a long period even when the limbal basal epithelium is largely missing.

To establish further the existence of limbal stem cells Tseng and coworkers used the antimetabolite 5-fluorouracil (5-FU) which also allows the identification of early progenitor cells because of its differentiation-inducing effect. Both in vitro and in vivo application of 5-FU showed that the limbal epithelium contained significantly more cells with stem cell characteristics than the corneal epithelium. ${ }^{60}$ These investigations confirmed the presence 
of stem cells and a pool of early progenitor cells which is present in both limbal and corneal epithelium.

In summary these studies suggest that the limbal epithelium contains a population of slow cycling cells which display the proliferative characteristics of stem cells. These cells are also resistant to the induction of differentiation. In addition, limbal, peripheral and central corneal epithelia seem to contain a population of very early transient amplifying cells which display some of the characteristics of stem cells.

Both the investigations of differentiation and the investigations of proliferation of limbal and corneal epithelium can be summarised by a model of the location of corneal epithelial stem cells as shown in Fig. 1. The stem cells are located exclusively in the limbal basal epithelium. The occurrence of transient amplifying cells in limited to the basal layer of limbal and corneal epithelia. Post-mitotic and terminally differentiated cells make up the superficial layers of limbal and corneal epithelia. This model describing the location of corneal epithelial stem cells in limbal basal epithelium is further supported by an analysis of the kinetic maintenance of the corneal epithelial mass. This mathematical model confirms that the corneal epithelium can be maintained by cellular proliferation originating from limbal stem cells without contribution of the adjacent conjunctiva. ${ }^{14}$

\section{IMPORTANCE OF CORNEAL STEM CELLS FOR THE REGENERATION OF THE CORNEAL EPITHELIUM}

The location of corneal epithelial stem cells in limbal basal epithelium suggests that the regeneration of corneal epithelium is highly dependent on the integrity of the limbus. This hypothesis is supported by two lines of experi-

LIMBUS

\section{CORNEA}

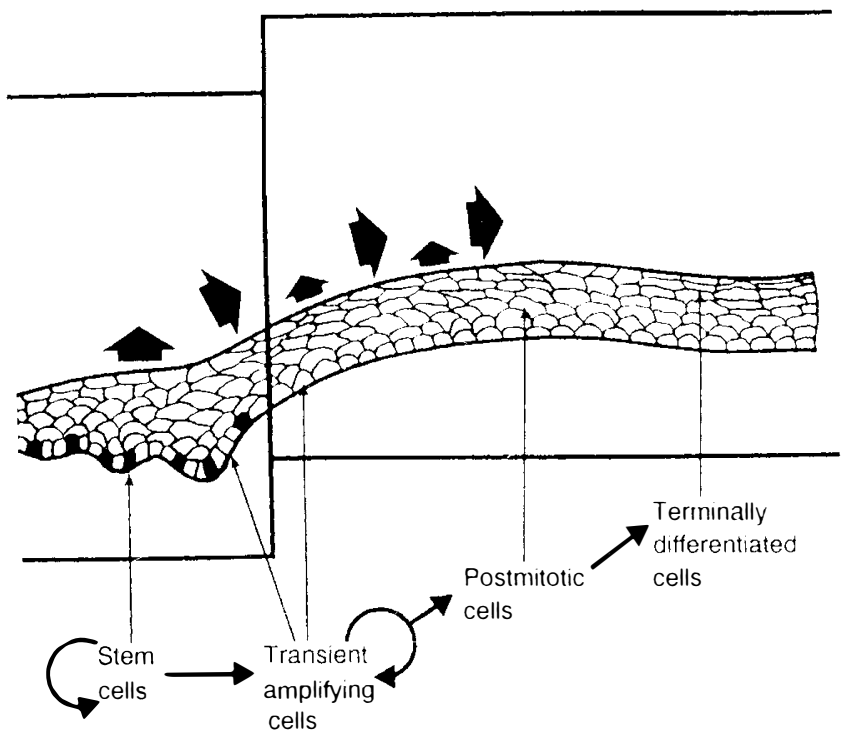

Fig. 1. Model of the limbal location of corneal stem cells. Stem cells (black) are exclusively located in the basal limbal epithelium. Transient amplifying cells occur only in the basal epithelia of limbus and cornea. Post-mitotic and terminally differentiated cells make up the superficial layers. mental evidence. First, the original corneal phenotype can not be maintained or reconstituted in the absence of stem cell-containing limbal epithelium. Second, the original phenotype of corneal epithelium can be reconstituted by surgical transplantation of limbal stem cells.

\section{Wound Healing in the Absence of Corneal Stem Cells}

The regeneration and maintenance of the corneal epithelium in response to partial or total removal of corneal stem cells at the limbus was investigated by a series of experiments performed on rabbits by Tseng and coworkers. ${ }^{61,63}$ In the presence of corneal stem cells within an uninjured limbal epithelium corneal epithelium regenerates despite repeated small central wounds, even if the total corneal epithelium is removed.

When corneal stem cells are depleted by removing two thirds of the limbal epithelium, the remaining stem and transient amplifying cells can maintain the corneal epithelium under physiological circumstances. This state of depletion of corneal stem cells has been named partial limbal deficiency. ${ }^{61}$ When the central corneal epithelium is removed in eyes with partial limbal deficiency, rapid wound healing was observed in $75 \%$ of the eyes even after two consecutive central woundings. ${ }^{61}$ This indicates that the remaining stem and transient amplifying cells not only maintain the epithelial mass but also regenerate the central corneal epithelium in the majority of the cases. On the other hand $25 \%$ of the eyes in which two thirds of the limbal epithelium was missing developed vascularisation and delayed wound healing, indicating that eyes with partial limbal deficiency are at risk of developing wound healing problems after the additional loss of central transient amplifying cells. When most of the transient amplifying cells were removed in eyes with partial limbal deficiency by creating a large defect of the central and peripheral corneal epithelium, all of the eyes investigated showed delayed wound healing, vascularisation and expression of a conjunctival phenotype. ${ }^{61}$ These findings indicate that the remaining stem cells could not generate enough transient amplifying cells to reconstitute the corneal epithelium and suggest a loss of the limbal barrier against the ingrowth of conjunctival epithelium on the surface of the cornea. These findings also support the importance of transient amplifying cells for the maintenance of the corneal epithelium. In particular the early transient amplifying cells which partially display stem cell characteristics and exist in both limbal and corneal epithelium ${ }^{59}$ maintain and regenerate the corneal epithelium even in the absence of a large portion of limbal stem cells.

When all the limbal stem cells are surgically removed resulting in a total limbal deficiency, the remaining transient amplifying cells maintain the corneal epithelial mass under physiological conditions in two thirds of the animals while the remaining develop mild vascularisation. ${ }^{62}$ After two consecutive central to mid-peripheral corneal woundings $75 \%$ of the corneas showed vascularisation and ingrowth of conjunctival epithelium. ${ }^{62}$ These results 
further support the importance of limbal stem cells but also indicate that even in the complete absence of stem cells a reconstitution of the corneal epithelium is possible if enough early transient amplifying cells are present. When transient amplifying cells are lost simultaneously with the surgical depletion of corneal stem cells $96 \%$ of the eyes show corneal neovascularisation and expression of a conjunctival phenotype in the epithelium which covers the cornea. ${ }^{3.3}$ This result confirms that absence of both stem and transient amplifying cells does not allow the reconstitution of a genuine corneal epithelium due to the total loss of the proliferative reserve. In the absence of the limbal proliferative barrier conjunctival epithelium grows onto the cornea and retains its phenotype in the presence of fast-developing neovascularisation.

Taken together the results of these animal experiments stress the importance of both corneal stem cells and transient amplifying cells for the maintenance and regeneration of the corneal epithelium. While both populations in the limbal epithelium easily maintain and regenerate the central and peripheral corneal epithelium, a partial or total loss of stem cells at the limbus can only be compensated if a sufficient amount of early transient amplifying cells remains in the corneal epithelium. In quantitative terms, it seems that up to $50 \%$ of the limbal epithelium is lost without conjunctival ingrowth and vascularisation if a sufficient amount of transient amplifying cells remains.

These experimental findings were also confirmed in human patients, where maintenance and healing of corneal epithelium is also dependent on the integrity of the limbus. Clinical studies of patients with chemical burns observed rapid, uncomplicated epithelial wound healing when the injury concerned only the central and peripheral corneal epithelium. ${ }^{10}$ When the corneal damage extended to the limbus, small defects in the limbal circumference are closed by sliding of the adjacent limbal epithelium, a process which reconstitutes the limbal barrier. If larger portions of the limbal circumference are destroyed $\left(180^{\circ}\right.$ or more), the lack of stem and transient amplifying cells results in ingrowth of conjunctival epithelium as well as in regional neovascularisation. ${ }^{10}$ Animal studies suggest that this kind of defect of the limbal barrier against the conjunctival epithelium also occurs when the entire corneal epithelium is missing and the suprabasal limbal epithelium is removed. ${ }^{6.3}$

\section{Transplantation of Corneal Stem Cells}

On the basis of the pathophysiological concept that a simultaneous loss of corneal stem and transient amplifying cell causes alterations of the corneal phenotype, Kenyon and Tseng ${ }^{64}$ suggested that the original corneal phenotype could be reconstituted by transplanation of healthy corneal stem cells. The effectiveness of this method for the treatment of experimentally induced limbal deficiency in rabbits was investigated by Tsai and coworkers..$^{65}$ In all eight eyes in which a simultaneous removal of limbal and corneal epithelium had caused aplasia of limbal stem cells with conjunctivalisation and neovascularisation, limbal transplantation significantly reduced the area of neovascularisation and allowed restoration of the corneal epithelial phenotype. ${ }^{65}$

The technique of conjunctival transplantation has earlier been suggested for the surgical reconstruction of vascularised corneas after chemical burns in human patients. ${ }^{66-68}$ To compare this method which was based on the hypothesis that corneal epithelium derives from conjunctival epithelium with limbal transplantation Tsai and coworkers $^{65}$ used both methods for the treatment of experimental limbal deficiency. The results showed that all but one of eight corneas which were treated by conjunctival transplantation developed progressive vascularisation with continuous expression of a conjunctival phenotype. A comparison with the above results after limbal transplanation confirms the importance of corneal stem cells at the limbus for the surgical reconstitution of the corneal epithelial phenotype.

\section{REGULATION OF CORNEAL STEM AND TRANSIENT AMPLIFYING CELLS}

Most of the current knowledge concerning epithelial stem cells is derived from investigations of haematopoietic progenitor cells, which were made possible by the development of single-cell clonal growth assays such as the spleen colony forming assay or the agarose assay. ${ }^{69,70}$ These model systems allow the development of single progenitor cells to be traced and their proliferative behaviour at different stages of the proliferative cascade to be investigated.

In order to gain insight into the regulation of the proliferation of corneal progenitor cells we developed a similar single-cell clonal growth assay which allows single corneal epithelial cells to be cultured in a serumfree defined culture medium. ${ }^{58.71}$ As mentioned before, presently available methods for the assessment of differentiation or proliferation do not permit differentiation between corneal stem and transient amplifying cells in a culture dish. However, the unique differential location of these cells in the limbal and corneal epithelium allows the separate investigation of these progenitor cell subpopulations. Anatomical separation of the limbal and corneal epithelium results in one cell population which contains both stem and transient amplifying cells (f rom the limbus) and a second cell population which contains only transient amplifying cells (from the cornea). A comparison of these populations in serum-free media showed a significant difference in the formation of colonies and their rate of proliferation, these being lower in limbal than in corneal cultures. ${ }^{58}$ This result, which is supported by labelling experiments in rabbits, ${ }^{5}$ can be explained by the slow cycling nature of stem cells in the limbal cell population and the lower number of fastcycling transient amplifying cells in limbal cultures. Furthermore, investigations of the differentiation of the colonies suggest that the culture conditions predominantly promote the proliferation of transient amplifying cells. ${ }^{58}$

A survey of various polypeptide growth factors such as 
epidermal growth factor (EGF) basic and acidic fibroblast growth factor (a and bFGF) or nerve growth factor (NGF) showed that these mitogens stimulate the proliferation of limbal and corneal epithelial cells in a similar way, indicating that they promote the common subpopulation of transient amplifying cells. ${ }^{72}$ The proliferation of transient amplifying cells was also promoted by increasing concentrations of extracellular calcium. ${ }^{73}$ In contrast to these stimulatory effects, transforming growth factor-beta (TGF- $\beta$ ) inhibited the proliferation of transient amplifying cells in both limbal and corneal cultures. ${ }^{72}$

While polypeptide growth factors and calcium also caused an almost identical pattern of differentiation in both limbal and corneal cultures, which supports their primary effect on transient amplifying cells, the addition of fetal bovine serum (FBS) resulted in a different response. While colony formation and proliferation of corneal cultures was reduced by increasing concentrations of FBS, the formation of limbal colonies and their proliferation was stimulated. ${ }^{74}$ These results indicate that factors in serum allow the preferential stimulation of a subpopulation of limbal epithelial cells which might represent stem cells while on the other hand transient amplifying cells in the corneal epithelium were inhibited. This interpretation was further supported by the observation of several morphologically distinct subsets of colonies present in limbal and corneal cultures. Due to the rapid differentiation of cells under the culture conditions employed in these studies the colonies most probably contained different types of transient amplifying cells some of which were the product of a recent conversion from stem cells. $^{74}$

One of the factors in serum which might be responsible for the presumed differentiation of limbal stem cells in retinoic acid. Retinoic acid is an important modulator of epithelial proliferation and differentiation which is present in serum in biologically active concentrations. ${ }^{75.76}$ Furthermore, the results of experiments with embryonal stem cells suggest that retinoic acid induces the differentiation of stem cells. ${ }^{77-79}$ Both limbal and corneal cultures exhibited a biphasic pattern of proliferation in response to increasing concentrations of retinoic acid ${ }^{80}$ While high concentrations above $10^{-6} \mathrm{M}$ inhibited the formation of colonies in both limbal and peripheral corneal cultures, lower concentrations had a differential effect on these cell populations. The colony formation in limbal cultures was increased by retinoic acid $\left(10^{-8}\right.$ or $\left.10^{-7} \mathrm{M}\right)$ but the colony formation in corneal cultures remained unchanged ${ }^{80}$ This differential stimulation of colony formation in limbal cultures allows us to speculate that limbal stem cells were preferentially differentiated to transient amplifying cells under the influence of retinoic acid. Furthermore, cultures containing $10^{-8} \mathrm{M}$ retinoic acid allowed the identification of morphologically distinct colony types, one of which was almost exclusively observed in limbal cultures. ${ }^{80}$ This result further supports the notion that retinoic acid acts on a special subpopulation of progenitor cells in the limbal epithelium, i.e. stem cells.

Taken together our investigations permit the construction of a hypothetical model of the regulation of corneal stem and transient amplifying cells (Fig. 2). The differentiation of stem to transient amplifying cells seems to be stimulated by serum factors one of which could be retinoic acid. The amplification of transient amplifying cells seems to be supported by polypeptide growth factors such as EGF, aFGF, bFGF or NGF and increasing concentrations of extracellular calcium. The amplification of transient amplifying cells seems to be inhibited by TGF- $\beta$ and serum factors such as retinoic acid.

The physiological meaning of some of these regulatory factors can be illustrated by the differential nutritional supply of limbal and corneal epithelium. The limbal epithelium is under the influence of the limbal vasculature while the cornea is avascular. ${ }^{81,82}$ Therefore, factors from serum such as retinoic acid might occur in limbal epithelium in higher concentrations than in corneal epithelium and the resulting concentration gradients could have regulatory functions. Furthermore, most of the polypeptide growth factors investigated by us have been proved to exist in the limbal and corneal epithelium. ${ }^{83-88}$ Interestingly, a recent investigation by $\mathrm{Li}$ and $\mathrm{Tseng}^{89}$ described significant regional differences concerning the distribution of growth factors in human limbal and corneal epithelium as well as underlying stroma. Several of the

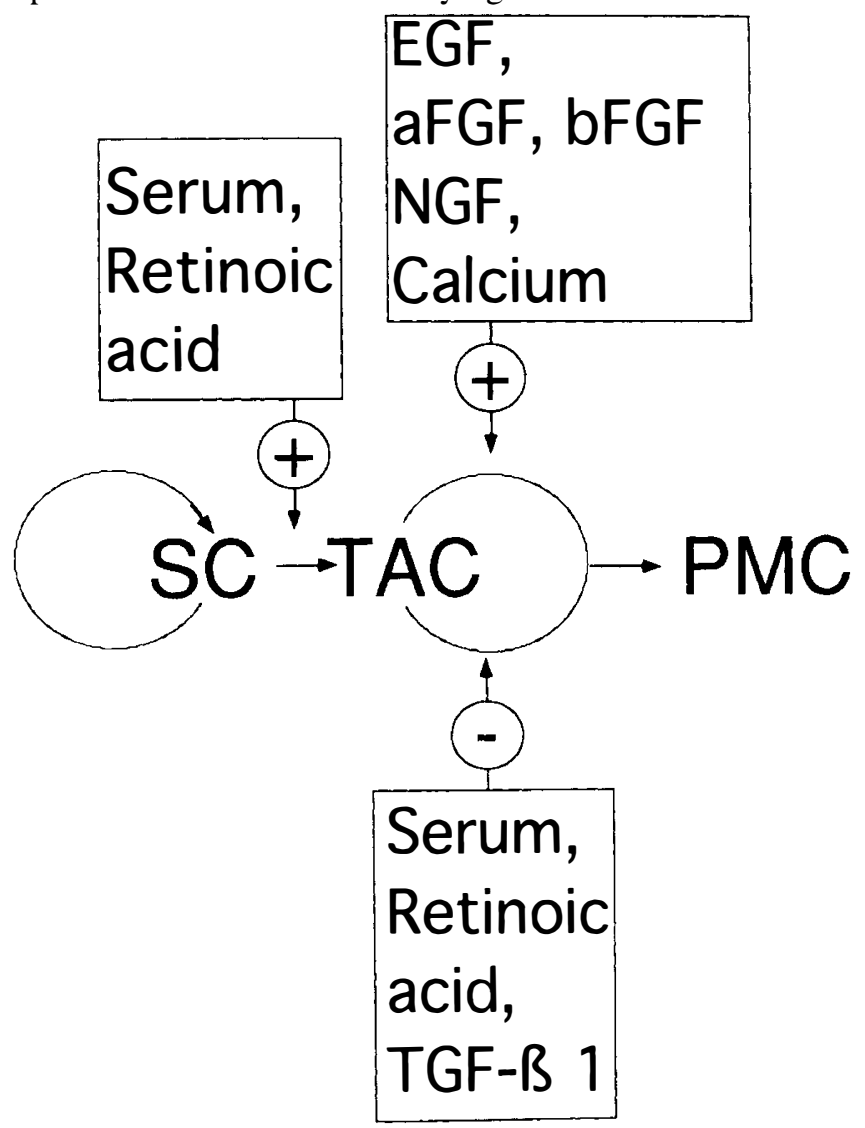

Fig. 2. Model of the regulation of corneal stem and transient amplifying cells. Conversion of stem cells (SC) to transient amplifying cells (TAC) is supported by serum factors such as retinoic acid. Amplification of TAC is promoted by epidermal growth factor $(E G F)$, acidic and basic fibroblast growth factor ( $a$ and $b F G F$ ) and nerve growth factor $(N G F)$ and calcium. Amplification of TAC is inhibited by retinoic acid and transforming growth factor-beta (TGF- $\beta 1)$ PMC, post-mitotic cells. 
investigated factors (e.g. members of the EGF and FGF family of growth factors) were expressed in the corneal epithelium while their receptors were observed in the underlying stroma or vice versa. ${ }^{89}$ Taken together, physiologically occurring regional differences in various regulatory factors might play a role in the regulation of limbal and corneal epithelium.

Besides regional concentration gradients of various factors, 'cross-talk' between different cell populations such as corneal epithelial and stromal cells might also have regulatory functions. The potential importance of mesenchymal cells such as embryonal fibroblasts for the regulation of epithelial cells can be concluded from a number of experiments. Using inactivated embryonal mouse fibroblasts (3T3 feeder layer) Rheinwald and Green ${ }^{90}$ were able to culture single keratinocytes for multiple passage. Application of this technique for clinical use makes it possible to expand the skin of burn victims and to regraft it successfully onto the patient. ${ }^{91.92}$ The long-term survival of the grafts in recipients suggests that these culture conditions preserve epithelial stem cells. This interpretation is further supported by experiments which show that 3T3 cells also allow the culture of haematopoietic stem cells. ${ }^{93}$ We and others were able to demonstrate that $3 \mathrm{~T} 3$ cells also allow the culture of corneal epithelial cells. ${ }^{94-96} \mathrm{~A}$ comparison of limbal cultures suggested that $3 \mathrm{~T} 3$ cells promote the proliferation of a subpopulation of cells which is present only in the limbal epithelium. ${ }^{95.96}$ Furthermore, 3T3 cells selectively allow the long-term culture of human limbal epithelial cells but not of corneal epithelial cells. ${ }^{97}$ These results suggest that factors from 3T3 cells may preserve stem cells or early transient amplifying cells.

One of the mechanisms by which 3T3 cells might modulate epithelial cells could be a change of their response to factors such as TGF- $\beta$ which inhibit epithelial cell proliferation and promote differentiation. ${ }^{98}$ As mentioned above, TGF- $\beta$ inhibited the colony formation and proliferation and induced differentiation in limbal and corneal epithelial cultures. ${ }^{99}$ However, the addition of 3T3 cells completely changes this response and actually promoted colony formation and proliferation in response to TGF- $\beta$ in concentrations up to $1.0 \mathrm{ng} / \mathrm{ml} .{ }^{99}$ Although this modulation needs further exploration a possible mechanism is the secretion of stimulatory factors by $3 \mathrm{~T} 3$ cells. Since such hypothetical factors should counteract differentiation and permit the amplification of corneal epithelial progenitor cells, their isolation could be of great therapeutic importance. As a first step towards the identification of such factors, we have recently shown that the conditioned medium from 3T3 cells contains factors which promote colony formation and proliferation of limbal and corneal epithelial cultures and that such factors possibly could be isolated from conditioned medium. ${ }^{100}$

Taken together these results suggest that stromal fibroblasts play a physiological role in the regulation of limbal and corneal epithelial cells and highlight the interplay between various regulatory factors as well as cell types in the regulation of corneal stem and transient amplifying cells.

\section{CLINICAL APPLICATION}

Although experimental evidence of the existence of corneal epithelial stem cells in the limbus is derived exclusively from animal studies it seems likely that human corneal stem cells are also located only in the basal limbal epithelium. This assumption is based on three lines of evidence: First, investigations of cellular differentiation show that the human basal limbal epithelium also lacks the expression of differentiation-related keratins (such as keratin K3) and expresses markers indicative of an undifferentiated phenotype (such as keratin K 19, vimentin or alpha-enolase) ${ }^{48-50,101}$ Second, the conjunctival phenotype which is expressed by corneas after the simultaneous loss of the corneal and limbal epithelium can be reconstituted into a corneal phenotype by transplantation of limbal stem cells. ${ }^{64.102}$ Third, circumstantial evidence for the existence of corneal stem cells is provided by the observation that neoplasms of the corneal epithelium, which can be interpreted as malfunctions of stem cells, almost always originate from the limbal epithelium. ${ }^{103,104}$

The concept of the location of human corneal epithelial stem cells in basal limbal epithelium can be used to improve the pathophysiological interpretation of various disorders of the ocular surface epithelium as well as to design therapeutic concepts for such diseases.

\section{Ocular Surface Disorders Caused by Malfunction or Absence of Corneal Stem Cells}

The absence or malfunction of corneal stem cells is characterised by the loss of the proliferative capacity of the corneal epithelium. Presumably due to the breakdown of the proliferative barrier at the limbus, conjunctival epithelium can grow onto the corneal surface and may be supported by newly formed vessels. The resulting clinical picture, which was initially described in humans by Tseng, ${ }^{40}$ can be characterised by analogy to the experimental removal of corneal stem cells in animal models.

The clinical symptoms may include decreased vision, photophobia, tearing, blepharospasm and recurrent episodes of pain, as well as a history of chronic inflammation with redness and oedema. The biomicroscopical findings at slit lamp examination may include a dull and irregular reflex of the corneal epithelium which is variable in thickness and opacification. The deep layers of the epithelium and anterior stroma may contain blood vessels and areas of opacification. Severe malfunction or absence of corneal epithelial stem cells may result in an ingrowth of thickened fibrovascular pannus as well as in calcifications. Histologically the ingrowth of conjunctival epithelium has been documented by the presence of goblet cells in impression cytology. ${ }^{105}$ Immunohistochemically both the absence of a cornea-type differentiation (such as the absence of keratin K3) as well as the presence of mucin in goblet cells has been shown by monoclonal antibodies. ${ }^{102.106}$

The aetiology of the absence or malfunction of stem cells can be classified as primary or secondary (Table I). Primary insufficiency of the limbal epithelium can be 
Table I. Aetiology of limbal insufficiency

\begin{tabular}{ll}
\hline Primary; & Anirida \\
& Congenital erythrokeratodermia \\
Secondary; & Chemical injury \\
& Thermal injury \\
& Contact lens wear \\
& Limbal surgery \\
\hline
\end{tabular}

characterised by the absence of external factors such as injuries, mechanical damage or pharmaceutical drugs. Although rare, two disease entities can be attributed to a loss or functional impairment of stem cells one of which is aniridia and the other congenital erythrokeratodermia. Many patients with aniridia express irregular and cloudy epithelium with corneal neovascularisations. By means of impression cytology goblet cells have been observed in the superficial corneal epithelium, which suggests an ingrowth of conjunctival epithelium due to loss of the limbal barrier. ${ }^{105.107}$ In congenital erythrokeratodermia, which was initially described by Burns, ${ }^{108}$ a clear but irregular corneal epithelium is traversed by blood vessels of seemingly conjunctival origin. We have recently observed goblet cells in the corneal epithelium of one patient with this rare disorder, which also suggests a loss of the limbal proliferative barrier possibly due to an impairment of corneal stem cells. ${ }^{109}$

The majority of ocular surface disorders which are caused by the absence or dysfunction of corneal stem cells are of secondary origin. Most importantly, chemical and thermal burns can cause variable limbal epithelial damage and ischaemia of the limbal vasculature. The extent of this damage is the cornerstone of various classifications regarding the prognosis after acute injury. ${ }^{110-11.3}$ Increased permeability of the limbal vasculature as well as cellular damage lead to an influx of leucocytes into the epithelium and stroma which alters the regulation of cellular proliferation and differentiation. ${ }^{11.114-116}$ In contrast to minor injuries in which a loss of corneal epithelium is combined with minor limbal damage, larger defects of the limbal circumference cannot heal by sliding of the adjacent healthy limbal epithelium..$^{10}$ In these cases, and after injuries in which severe inflammation resulted in regulatory dysfunction of the limbal epithelium, a localised loss of the limbal barrier occurs with consecutive invasion of conjunctival epithelium. ${ }^{10.15 .115 .117}$

A combination of mechanical, toxic and inflammatory factors with hypoxia may lead to limbal insufficiency in contact lens wearers. ${ }^{118.119}$ The clinical triad of corneal neovascularisation, epithelial abnormalities (such as indolent ulceration and irregularities with whorled pattern) and stromal opacities has been called contact-lens-related epithelial dysfunction. ${ }^{120}$ Although there are no published histological investigations regarding eyes with this disorder, which is unresponsive to all conservative treatment, the successful reconstitution of the ocular surface by autologous limbal transplantation ${ }^{64.120}$ further supports the idea that a dysfunction of limbal stem cells is the key pathogenetic factor in the development of this disorder.

Several surgical manipulations in the area of the limbal epithelium can also cause permanent dysfunction of limbal stem cells. Examples are excision of limbus-based suspicious neoplastic malformations such as squamous cell carcinoma or corneal intra-epithelial neoplasms, excision of recurrent pterygium and cryosurgery of the ciliary body which is performed in the proximity of the limbus. The resulting dysfunction of the limbal epithelium has successfully been treated by autologous limbal transplantation. ${ }^{64,121}$

\section{Treatment of Depletion or Malfunction of Corneal Stem Cells by Limbal Transplantation}

As long as limited insight into the regulation of proliferation and differentiation of limbal stem cells prevents the development of a conservative treatment, surgical intervention serves as the only means of reconstituting the ocular surface following disorders caused by limbal insufficiency. However, conservative surgical treatment of limbal insufficiency, for example, after chemical burns, by procedures such as lamellar or perforating keratoplasty generally has a very poor prognosis. ${ }^{122-126}$ This can be explained by the fact that transplantation of the central or peripheral corneal epithelium results only in the substitution of transient amplifying cells with a limited proliferative capacity and life span. ${ }^{26}$ Therefore, conventional keratoplasty provides only a temporary replacement of the host's corneal epithelium ${ }^{8.127}$ and does not permanently reconstitute the limbal barrier. In order to improve the limited success of the conservative surgical treatment of chemical burns Thoft $\mathrm{ft}^{\mathrm{t}-68}$ initially suggested the procedure of conjunctival transplantation. This method was developed on the theory of a conjunctival derivation of the corneal epithelium. On the basis of the stem cell model Kenyon and Tseng ${ }^{64}$ further modified the technique of conjunctival transplantation to include the limbal epithelium. Thus, the surgical procedure of limbal transplantation results in transfer of limbal epithelium containing long-living corneal stem cells.

The principle of the procedure, which is shown in Fig. 3, involves first the removal of altered corneal epithelium with removal of the pannus down to the bare sclera. Then a superficial keratectomy can be made in the periphery of the cornea extending into the sclera to create a bed for the limbal graft. The graft is then harvested from the donor eye in the form of two stripes of tissue each measuring about 4 clock-hours (for autografts). In the case of an allograft transplantation a ring graft containing $360^{\circ}$ of limbal tissue can be prepared from the donor eye as shown in the illustration. In the light of the importance of the limbal and corneal stroma for the regulation of the corneal epithelium a sufficient portion of limbal stroma should be included in the graft. The graft is then transfered onto the host and fixed at its corneal, scleral and conjunctival margins. From this ring of limbal tissue transient amplifying cells are generated which migrate onto the denuded corneal surface of the host. After successful transplantation the host's cornea will be permanently covered by epithelium from the donor. 


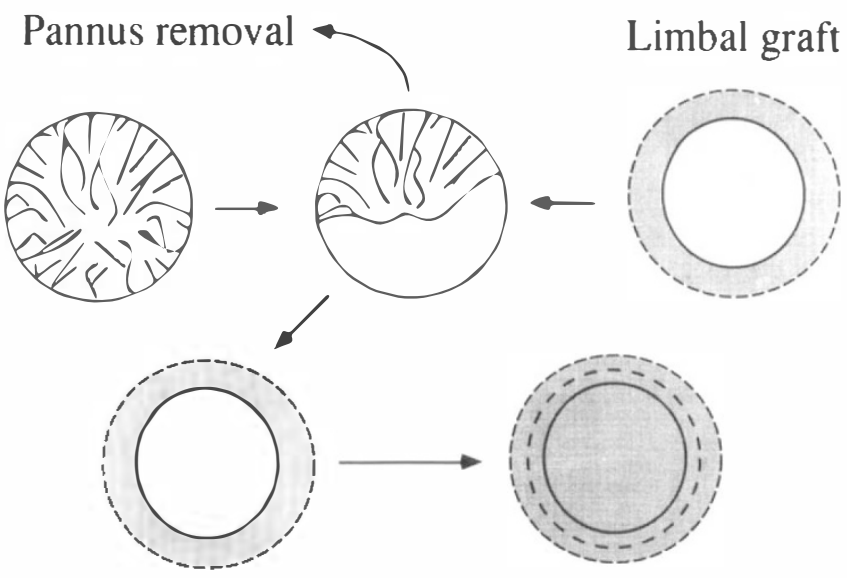

Fig. 3. Principle of limbal transplantation. The procedure involves the following steps; removal of fibrovascular tissue from host, preparation of limbal graft from donor, transfer of graft to host and fixation at limbus. Reconstitution of host's corneal phenotype from donor occurs following successful transplantation.

In their original report Kenyon and Tseng ${ }^{64}$ described 26 limbal autografts, 20 of which resulted in stable epithelium without recurrent erosions and 15 in regression of the corneal neovascularisation. Since their original report the procedure of limbal autograft transplantation has gained acceptance and several small series have been reported with good reconstitution of the corneal epithelium and regression of neovascularisation. ${ }^{120.128}$ Although autologous transplantation has significantly enhanced the surgical armamentarium for treatment of unilateral limbal insufficiency, it is not applicable in bilateral cases which frequently develop after injuries such as chemical burns. Such patients could be treated by heterologous limbal transplantation. However, this procedure carries a significant risk of graft rejection because the limbal tissue is grafted into a highly vascular bed which does not enjoy the immunological privilege of the avascular cornea. Since Weise and coworkers ${ }^{129}$ demonstrated the feasibility of conjunctival allografts in humans several years ago, it seemed justifiable also to perform limbal allografts in patients with bilateral legal blindness due to severe bilateral limbal deficiency. Although no clinical study has been published, initial experience by Tseng disclosed a 30\% chance of graft rejection in non-tissue-matched grafts. ${ }^{130}$ Subsequent use of oral cylosporin A in addition to oral steroids by Tsai and coworkers has significantly reduced the risk of allograft rejections and allowed successful grafts in 12 patients. ${ }^{130}$ Similar to the use of oral cyclosporin $\mathrm{A}$ in perforating keratoplasty, where the drug is administered for a minimum of 6-12 months, ${ }^{131}$ patients with a limbal transplant should be treated for an equally long period. Since the long-term use of cyclosporin A can result in serious side effects we evaluated the local administration of the drug concerning the concentration in limbal tissue. First results of this study showed no significant difference in the concentration after systemic or topical administration. ${ }^{132}$ It therefore seems justfiable to discontinue oral cyclosporin after a period of 12 weeks and to continue topical medication for another 9 months.
Under this therapeutic regimen long-term rehabilitation of bilateral limbal insufficiency can be achieved. ${ }^{133}$ The eye of a representative patient with partial limbal insufficiency due to multiple surgery for recurrent pterygium is shown prior to limbal allograft transplantation with epithelial opacities and superficial as well as deep stromal vessels in Fig. 4 (above). One year after limbal allograft transplantation in both nasal quadrants the limbal epithelium is restored by a zone of clear cornea without recurrence of the vessel ingrowth (Fig. 4, below). The central epithelium, which was removed to the level of Bowman's layer, was rapidly substituted from the grafted epithelium. Furthermore, the opacified stroma which was not touched by the surgery cleared remarkably over the course of the year, resulting in an improvement in visual acuity from $1 / 50$ to $20 / 35$. Such a remarkable diminution of stromal opacities was also observed after limbal autograft transplantation $^{64}$ and might be due to an epithelial-stromal interaction. However, in most cases a second surgical intervention such as lamellar or penetrating ketratoplasty is needed for complete visual rehabilitation. In summary, the procedure of limbal allograft transplantation as initially described by Tseng and coworkers ${ }^{130}$ has proved to be a valuable tool in the reconstruction of bilateral limbal insufficiencies.

\section{CONCLUSION}

A wide body of experimental and clinical data support the model of the limbal location of corneal epithelial stem cells. Although the importance of these long-lived progenitor cells for the integrity and regeneration of the corneal epithelial phenotype is evident, several open questions remain. One of these concerns the positive identification of stem cells. Although several antibodies have been developed neither stem cells, transient amplifying cells nor post-mitotic cells can currently be differentiated. Also, almost nothing is known about the regulation of the self-renewal of stem cells and their resistance to differentiation-inducing agents. The lack of suitable model systems as well as the enormous complexity of the regulatory mechanisms have until now precluded investigation of these important questions. However, an increasing number of cytokines are currently being studied and investigation of the interaction of various cell types (such as epithelial and stromal cells) might eventually enable the identification of an environmental niche which governs the regulation of stem cells. The identification of factors which prevent the differentiation of stem cells and allows their amplification has enormous clinical potential. Such factors would allow for a conservative treatment of ocular surface disorders which are due to stem cell loss or dysfunction. Therefore, these factors would overcome the limitations of the current treatment of ocular surface disorders with growth factors. These limitations can be extrapolated from the regulatory model shown in Fig. 2. All the factors which are included in this model promote the differentiation of either stem cells or transient amplifying cells and therefore cannot be used for the treatment of limbal insufficiency. 


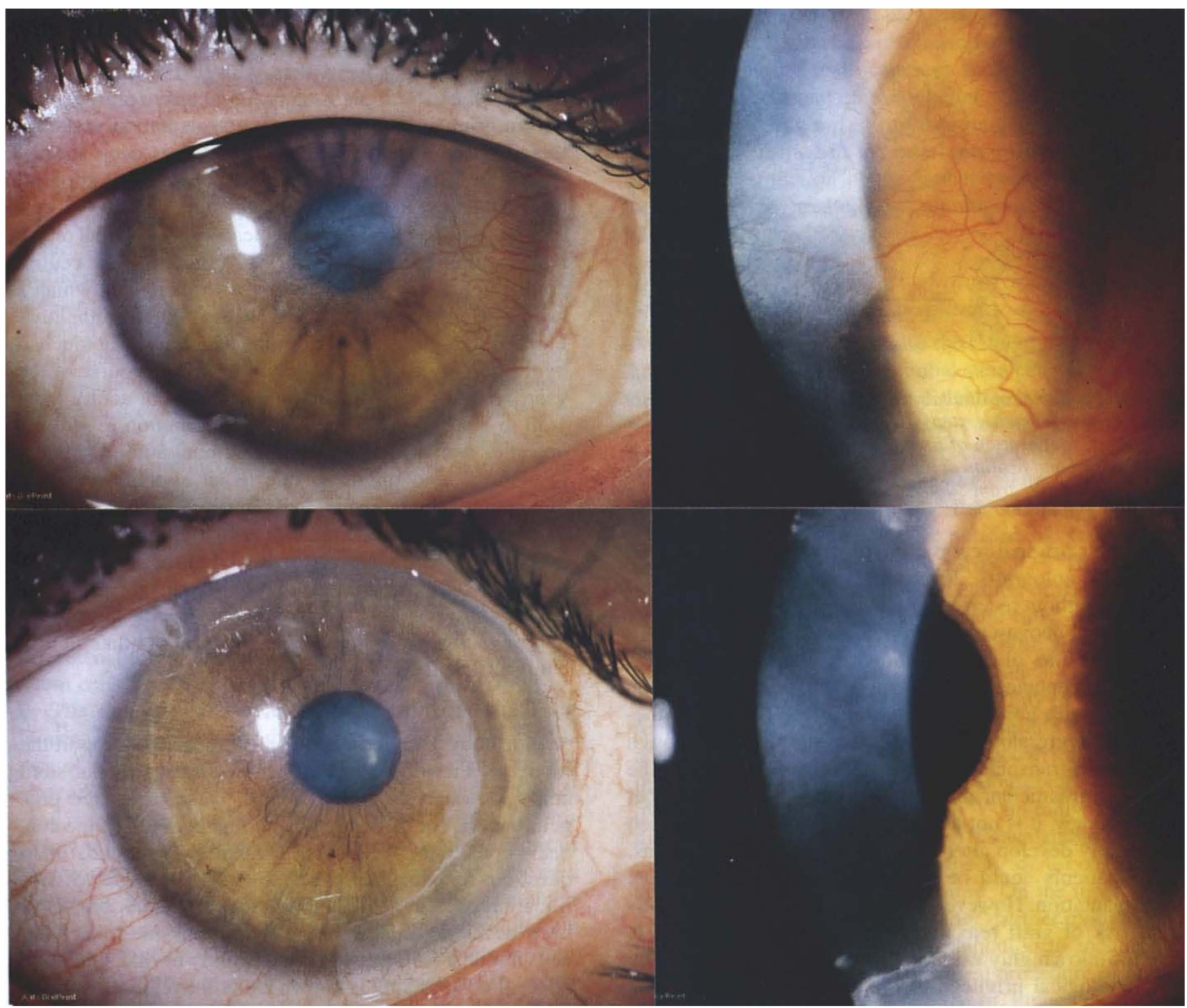

Fig. 4. Case report of limbal allograft transplantation. Limbal insufficiency of both nasal quadrants due to multiple surgery prior to current surgery (left upper quadrant). Central cornea with opacification and neovascularisation (right upper quadrant). Nasally located graft 1 year after limbal allograft (left lower quadrant). Central cornea after surgery with resolution of the deep opacifications in the avascular cornea (right lower quadrant).

The investigation of corneal stem cells has significantly enhanced our understanding of ocular surface disorders and has led to the development of new therapeutic procedures. In particular bilateral limbal insufficiencies, mostly due to chemical burns, can be successfully rehabilitated by limbal allografts. However, more experience with this procedure needs to be gathered, especially concerning the signs of graft rejection, which are presently ill defined. It is to be hoped that the enhancement of our basic knowledge concerning stem cell perpetuation might eventually allow us to expand single stem cells in culture and to use them for reconstitution of the ocular surface.

This investigation was supported in part by a grant from Dentsche Forschungsgemeinschaft (Kr 993/1-1).

Key words: Cornea, Epithelium, Growth factors, Keratoplasty, Limbus, Stem cells.

\section{REFERENCES}

1. Buschke W, Friedenwald JS, Fleischmann W. Studies on the mitotic activity of the corneal epithelium. Johns Hopkins Hosp Bull 1943;72;143.

2. Kaufmann B, Gay H, Hollaender A. Distribution of mitoses in the corneal epithelium of the rabbit and the rat. Anat Rec 1944;90;161.

3. Hanna C, O'Brien JE. Cell proliferation and migration in the epithelial layer of the cornea. Arch Ophthalmol 1960; $64 ; 536$.

4. Hanna C, Bicknell DS, O'Brien JE. Cell turnover in the adult human eye. Arch Ophthalmol 1961;65;111.

5. Lavker RM, Dong G, Cheng SZ, Kudoh K, Cotsarelis G, Sun TT. Relative proliferative rates of limbal and corneal epithelia. Invest Ophthalmol Vis Sci 1991;32;1864.

6. Kuwabara T, Perkins DG, Cogan DG. Sliding of the epithelium in experimental corneal wounds. Invest Ophthalmol Vis Sci $1976 ; 15 ; 4$.

7. Buck RC. Cell migration and repair of mouse cornea epithelium. Invest Ophthalmol Vis Sci 1979;18;767. 
8. Kinoshiota S, Friend J, Thoft RA. Sex chromatin of donor corneal epithelium in rabbits. Invest Ophthalmol Vis Sci $1981 ; 21 ; 434$.

9. Buck RC. Measurement of centripetal migration of normal corneal epithelium in the mouse. Invest Ophthalmol Vis Sci $1985 ; 26 ; 1296$.

10. Dua HS, Forrester JV. The corneoscleral limbus in human corneal epithelial wound healing. Am J Ophthalmol 1990; $110 ; 545$.

11. Kaye DB. Epithelial response in penetrating keratoplasty. Am J Ophthalmol 1980;89;381.

12. Lemp MA, Mathers WD. Corneal epithelial cell movement in humans. Eye 1989;3;438.

13. Thoft RA, Friend J. The X, Y, Z hypothesis of corneal epithelial maintenance. Invest Ophthalmol Vis Sci 1983;24; 1442.

14. Sharma A, Coles WH. Kinetics of corneal epithelial maintenance and graft loss. Invest Ophthalmol Vis Sci 1989;30; 1962.

15. Mann I, Pullinger BD. A study of mustard gas lesions of the eyes of rabbits and man. Proc R Soc Med 1942;35;229.

16. Maumanee AE, Scholz RO. Histopathology of the ocular lesions produced by sulfur and nitrogen mustard. John Hopkins Hosp Bull 1948;82;121.

17. Friedenwald JS, Buschke W, Scholz RO. Effects of mustard and nitrogen mustard on mitotic and wound healing activities of the corneal epithelium. Johns Hopkins Hosp Bull 1948;82;148.

18. Friedenwald J. Growth pressure and metaplasia of conjunctival and corneal epithelium. Doc Ophthalmol 1951; $5-6 ; 184$.

19. Friend J, Thoft RA. Functional competence of regeneration ocular surface epithelium. Invest Ophthalmol Vis Sci 1978; $17 ; 134$.

20. Shapiro MS, Friend J, Thoft RA. Corneal re-epithelialization from the conjunctiva. Invest Ophthalmol Vis Sci $1981 ; 21 ; 135$.

21. Kinoshita S, Kiorpes TC, Friend J, Thoft RA. Limbal epithelium in ocular surface wound healing. Invest Ophthalmol Vis Sci 1982;23;73.

22. Kinoshita S, Friend J, Thoft RA. Biphasic cell proliferation in transdifferentiation of conjunctival to corneal epithelium in rabbits. Invest Ophthalmol Vis Sci $1983 ; 24 ; 1008$.

23. Buck RC. Ultrastructure of conjunctival epithelium replacing corneal epithelium. Curr Eye Res 1986;5;149.

24. Thoft RA, Friend J. Biochemical transformation of regenerating ocular surface epithelium. Invest Ophthalmol Vis Sci $1977 ; 16 ; 14$.

25. Kinoshita S, Friend J, Kiorpes TC, Thoft RA. Keratin-like proteins in corneal and conjunctival epithelium are different. Invest Ophthalmol Vis Sci 1983;24;577.

26. Harris TM, Berry ER, Pakurar AS, Sheppard LB. Biochemical transformation of bulbar conjunctiva into corneal epithelium; an electrophoretic analysis. Exp Eye Res 1985; 41;597.

27. Huang AJW, Watson BD, Hernandez E, Tseng SCG. Induction of conjunctival transdifferentiation on vascularized corneas by photothrombotic occlusion of corneal neovascularization. Ophthalmology 1988;95;228

28. Tseng SCG, Hatchell D, Tierney N. Expression of specific keratin markers by rabbit corneal, conjunctival and esophageal during vitamin A deficiency. J Cell Biol 1984;99; 2279.

29. Farazdaghi M, Lui SH, Rider AA, Tseng SCG. Reversal of conjunctival transdifferentiation by retinoids. Invest Ophthalmol Vis Sci 1984;25;76.

30. Tseng SCG, Hirst LW, Faradzaghi M, Green WR. Inhibition of conjunctival transdifferentiation by topical retinoids. Invest Ophthalmol Vis Sci 1987;28;538.

31. Tseng SCG, Faradaghi M, Ryder AA. Conjunctival trans- differentiation induced by systemic vitamin A deficiency in vascularized rabbit corneas. Invest Ophthalmol Vis Sci $1987 ; 28 ; 1497$

32. Cintron C, Hasslinger L, Kublin CL, Friend J. A simple method for removal of rabbit corneal epithelium utilizing n-heptanol. Ophthalmic Res 1979;11;90.

33. Kruse FE, Chen JJY, Tsai RJF, Tseng SCG. Conjunctival transdifferentiation is due to incomplete removal of limbal basal epithelium. Invest Ophthalmol Vis Sci 1990;31; 1903.

34. Davanger M, Evensen A. Role of the pericorneal peripapillary structure in renewal of corneal epithelium. Nature $1971 ; 229 ; 560$.

35. Schermer A, Galvin S, Sun TT. Differentiation related expression of major $64 \mathrm{~K}$ keratin in vivo and in culture suggests limbal location of corneal epithelial stem cells. J Cell Biol 1986;103;49.

36. Potten CS. Epithelial proliferative subpopulations. In Lord BI, Potten CS, Cole RJ, editors. Stem cells and tissue homeostasis. Cambridge; Cambridge University Press, $1978 ; 317$.

37. Lebold CP. The life history of cells in renewing systems. Am J Anat 1981;160;114.

38. Lathja LG. Stem cell concepts. Differentiation 1979;14;23.

39. Lavker RM, Cotsarelis G, Dong G, Hardy C, Schermer A, Sun TT. Limbal location of corneal epithelial stem cells. In; HD Cavanagh, editor. The cornea. Transactions of the world congress on the cornea III. New York; Raven Press, 1988:23.

40. Tseng SCG. Concept and application of limbal stem cells Eye 1989;3;141.

41. Spangrude GJ, Heimfeld S, Weissman IL. Purification and characterization of mouse hematopoietic stem cells. Science 1989;241;58.

42. Moll R, Franke WW, Schiller DL, Geider B, Krepler R. The catalog of human cytokeratins; patterns of expression in normal epithelia, tumors and cultured cells. Cell 1982; $31 ; 11$.

43. Cooper D, Schermer A, Sun TT. Classification of human epithelia and their neoplasms using monoclonal antibodies to keratins; strategies, applications, and limitations. Lab Invest $1985 ; 52 ; 243$.

44. Tseng SCG, Jarvinen MJ, Nelson WG, Hunag J, Woodcock-Mitchell, Sun TT. Correlation of specific keratins with different types of epithelial differentiation; monoclonal antibody studies. Cell 1982;30;361.

45. Woodcock-Mitchell JR, Eichner WG, Nelson WG, Sun TT. Immunolocalization of keratin polypeptides in human epidermis using monoclonal antibodies. J Cell Biol 1988; 95;580.

46. Chaloin-Dufau C, Sun TT, Dhouailly D. Appearance of the keratin pair K3/K12 during embryonic and adult corneal epithelial differentiation in the chick and in the rabbit. Cell Differ Dev 1990;32;97.

47. Kurpakus MA, Stock EL, Jones JCR. Expression of the 55$\mathrm{kD} / 64-\mathrm{kD}$ corneal keratins inocular surface epithelium. Invest Ophthalmol Vis Sci 1990;31;448.

48. Kasper M, Moll R, Stosiek P, Karsten U. Patterns of cytokeratin and vimantin expression in the human eye. Histochemistry $1988 ; 89 ; 369$.

49. Lauweryns B, van den Oord JJ, De Vos R, Missotten L. A new epithelial cell type in the human cornea. Invest Ophthalmol Vis Sci 1993;34;1983.

50. Zieske JD, Bukusoglu G, Yankauchas MA. Characterization of a potential marker of corneal epithelial stem cells. Invest Ophthalmol Vis Sci 1992;33;1.43.

51. Zieske JD, Bukusoglu G, Yankauchas MA, Keutmann HT. A 50-kD protein present in limbal basal cells of limbal epithelium is enolase. Invest Ophthalmol Vis Sci 1991;32; 1073. 
52. Withers RH. Colony forming units in the intestine. In; Cairnie AB, Lala PK, Osmond DG, editors. Stem cells of renewing cell populations. New York; Academic Press, 1976;33.

53. Bickenbach JR. Identification and behaviour of labelretaining cells in oral mucosa and skin. J Dent Res 1981; $60 ; 1611$.

54. Cotsarelis G, Cheng S-Z, Dong G, Sun TT, Lawker RW. Existence of slow-cycling limbal basal cells that can be preferentially stimulated to proliferate; implications on limbal stem cells. Cell 1989;57;201.

55. Yuspa SH, Ben TB, Hennings H, Lichti U. Divergent response in epidermal basal cells exposed to the tumor promoter 12-O-tetradecanylphorbol-13-acetate. Cancer Res $1982 ; 42 ; 2344$

56. Hawley-Neslon P, Stanley JR, Schmidt J, Gullino M, Yuspa SH. The tumor promoter, 12-O-tetradecanylphorbol-13-acetate, accelerates keratinocyte differentiation and stimulates growth of an unidentified cell type in cultured human epidermis. Exp Cell Res 1982;137;155.

57. Hesterberg TW, Manesse SC, Iglehart JD, Sanchez JH, Boreiko CJ. Subpopulations of human bronchial epithelial cells in culture respond heterogeneously to 12-O-tetradecanylphorbol-13-acetate (TPA) and other modulators of differentiation. Carcinogenesis 1987;8;1511.

58. Kruse FE, Tseng SCG. A serum-free clonal growth assay for limbal, peripheral and central corneal epithelium. Invest Ophthalmol Vis Sci 1991;32;2086.

59. Kruse FE, Tseng SCG. A tumor promoter-resistant subpopulation is larger in limbal epithelial than in corneal epithelium. Invest Ophthalmol Vis Sci 1993;34;2501.

60. Tseng SCG, Zhang SH. Slow cycling nature of limbal epithelium demonstrated by 5-FU resistance. Invest Ophthalmol Vis Sci 1992;33;1176.

61. Chen JJY, Tseng SCG. Corneal epithelial wound healing in partial limbal deficiency. Invest Ophthalmol Vis Sci 1990; $31 ; 1301$.

62. Huang AJW, Tseng SCG. Corneal epithelial wound healing in the absence of limbal epithelium. Invest Ophthalmol Vis Sci 1991;32;96.

63. Chen JJY, Tseng SCG. Abnormal corneal epithelial wound healing in partial-thickness removal of limbal basal epithelium. Invest Ophthalmol Vis Sci 1991;32;2219.

64. Kenyon KR, Tseng SCG. Limbal autograft transplantation for ocular surface disorders. Ophthalmology 1989;96;709.

65. Tsai RJF, Sun TT, Tseng SCG. Comparison of limbal and conjunctival autograft transplantation in corneal surface reconstruction in rabbits. Ophthalmology 1990;97;446.

66. Thoft RA. Conjunctival transplantation. Arch Ophthalmol 1977;95;1425

67. Thoft RA. Conjunctival transplantation as an alternative for keratoplasty. Ophthalmology 1979;86;1084.

68. Thoft RA. Indications for conjunctival transplantation. Ophthalmology 1982;89;335.

69. Becker AJ, McCulloch EA, Till JE. Cytological demonstration of the clonal nature of spleen colonies derived from transplanted mouse marrow cells. Nature 1963;197;453.

70. Plutznik DH, Sachs L. The cloning of normal 'mast' cells in tissue culture. J Cell Comp Physiol 1965;66;319.

71. Kruse FE, Tseng SCG. Zur Untersuchung des Limbusepithels in vitro. Fortschr Ophthalmol 1991;88;107.

72. Kruse FE, Tseng SCG. Growth factors modulate clonal growth and differentiation of cultured rabbit limbal and corneal epithelium. Invest Ophthalmol Vis Sci 1993;34; 1963.

73. Kruse FE, Tseng SCG. Proliferative and differentiative response of corneal and limbal epithelium to extracellular calcium in serum-free clonal cultures. J Cell Physiol 1992; $151 ; 347$.

74. Kruse FE, Tseng SCG. Serum differentially modulates the clonal growth and differentiation of cultured limbal and corneal epithelium. Invest Ophthalmol Vis Sci 1993;34; 2976.

75. Fuchs E, Green H. Regulation of terminal differentiation of cultured human keratinocytes by vitamin A. Cell 1981;25; 617.

76. Hashimoto T, Dykes PJ, Marks R. Retinoic acid-induced inhibition of growth and reduction of spreading of human epidermal cells in culture. Br J Dermatol 1985;112;637.

77. Strickland S, Mahavi V. The induction of differentiation in teratocarcinoma stem cells by retinoic acid. Cell 1978;15; 393.

78. Breitman TR, Selonick S, Collins S. Induction of differentiation of the human promyelocytic cell line (HL-60) by retinoic acid. Proc Natl Acad Sci USA 1980;77;2936.

79. Sherman ML, Mattheai KI, Schindler J. Studies on the mechanism of induction of embryonal carcinoma cell differentiation by retinoic acid. Ann NY Acad Sci 1981;359; 192.

80. Kruse FE, Tseng SCG. Retinoic acid modulates clonal growth and differentiation of cultured limbal and peripheral corneal epithelium. Invest Ophthalmol Vis Sci 1993 (in press).

81. Buskirk EM van. The anatomy of the limbus. Eye 1989;3; 101.

82. McCulley JP. The circulation of fluid at the limbus (flow and diffusion at the limbus). Eye 1989;3;114.

83. Caruelle D, Groux-Muscatelli B, Gaudric A, Sestier C, Casocas G, Caruelle JP, Barritault D. Immunological study of acidic fibroblast growth factor ( $\mathrm{aFGF}$ ) distribution in the eye. J Cell Biochem 1989;39;117.

84. Baudouin C, Fredj-Reygrobellet D, Caruelle JP, Barritault D, Gastaud D, Lapalus P. Acidic fibroblast growth factor distribution in normal eye and possible implication in ocular pathogenesis. Ophthalmol Res 1990;22;73.

85. Adamis AP, Meklir B, Joyce NC. Immunohistochemical distribution of basic-fibroblast growth factor in the cornea. Invest Ophthalmol Vis Sci 1991;32;955.

86. Wilson SE, He Y G, Lloyd SA. EGF, basic FGF and TGF- $\beta$ messenger RNA production in rabbit corneal epithelial cells. Invest Ophthalmol Vis Sci 1992;33;1987.

87. Wilson SE, He YG, Lloyd SA. EGF, EFG-receptor, basic FGF, TGF- $\beta 1$, and IL-1a mRNA in human corneal epithelial cells and stromal fibroblasts. Invest Ophthalmol Vis Sci 1992;33;1756.

88. Schultz GS, Khaw PT, MacKay SLD, Chegini N, Rotatori DS, Adams JL, Shimizu RW. Human corneal epithelium; autocrine production of transforming growth factor-alpha mRNA and protein. Invest Ophthalmol Vis Sci 1992;33; 1028.

89. Li DQ, Tseng SCG. Cytokine network between human limbal or corneal epithelium and fibroblasts. Invest Ophthalmol Vis Sci 1993;34;1011.

90. Rheinwald JG, Green H. Serial cultivation of strains of human epidermal keratinocyte; the formation of keratinizing colonies from single cells. Cell 1975;6;331.

91. Green H, Kehinde O, Thomas J. Growth of cultured epidermal cells into multiple epithelia suitable for grafting. Proc Natl Acad Sci USA 1979;76;5665.

92. O'Connor N, Mulliken JB. Banks-Schlegel S, Kehunde O, Green H. Grafting of burns with cultured epithelium prepared from autologous epidermal grafts. Lancet 1981;10; 75.

93. Roberts RA, Spooncer E. Parkinson EK, Lord BI, Allen TD, Dexter TM. Metabolically inactive 3 T3 cells can substitute for marrow stromal cells to promote the proliferation and development of multipotent haematopietic stem cells. J Cell Physiol 1987;132;203.

94. Sun TT, Green H. Cultured cells of cornea, conjunctiva and skin; absence of marked intrinsic divergence of their differentiated states. Nature 1977;269;489. 
95. Kruse FE, Tseng SCG. Comparison of single cell clonal growth of corneal and limbal epithelium in serum free defined culture and 3T3 feeder layer. J Cell Biol 1989;109; $329 \mathrm{a}$.

96. Tseng SCG, Kruse FE. Comparison of single cell clonal growth of limbal and corneal epithelium in serum free defined medium and 3T3 feeder layer. Invest Ophthalmol Vis Sci 1990;31;538.

97. Lindberg K, Chaves HV, Shams NBK, Kenyon KR, Rheinwald JG. Serial propagation of human ocular surface epithelial cells and reconstruction of differentiated epithelia. Invest Ophthalmol Vis Sci 1992:33:1176.

98. Masui T, Wakefield LM, Lechner JF. LaVeck MA, Sporn $\mathrm{MB}$, Harris CC. Type beta transforming growth factor is the primary differentiation-inducing serum factor for normal human bronchial epithelial cells. Proc Natl Acad Sci USA $1986 ; 83 ; 2438$.

99. Kruse FE, Tseng SCG. Inhibitory effect of TGF- $\beta$ on corneal epithelial proliferation can be reversed by fibroblasts coculture. Invest Ophthalmol Vis Sci 1992;33;1028.

100. Kruse FE. Tseng SCG. Epithelial growth is promoted by a mitogen from fibroblast conditioned medium. Invest Ophthalmol Vis Sci 1993;34;1011.

101. Thoft RA, Wiley LA, Sunderraj N. The multiponetial cells of the limbus. Eye 1989;3:109.

102. Kenyon KR, Bulusoglu G, Zieske JD. Clinical pathologic correlations of limbal autograft transplantation. Am J Ophthalmol 1990;31;1.

103. Waring GO III, Roth AM, Elkins MB. Clinical and pathologic description of 17 cases of corneal intraepithelial neoplasia. Am J Ophthalmol 1984:97:547.

104. Garner A. The pathology of tumors at the limbus. Eye 1989:3:210

105. Tseng SCG. Application of corneal impression cytology to study conjunctival transdifferentiation defect. In; Orsoni JG, editor. Ophthalmic cytology. Proceedings of the first international symposium on ophthalmic cytology. Parma; Centro grafica editoriale, Universita degli studi di Parma, 1988:65.

106. Huang AJW, Tseng SCG. Development of monoclonal antibodies to rabbit ocular mucin. Invest Ophthalmol Vis Sci $1987 ; 28 ; 1483$.

107. Nishida K. Kinoshita, Ohashi Y, Kuwayama Y. Ocular surface abnormalities in aniridia. Jpn J Clin Ophthalmol 1993; $47 ; 625$.

108. Burns FS. A case of generalized congenital keratodermia. J Cutan Dis 1915;33;255.

109. Kruse FE, Rohrschneider K, Blum M, Völcker HE, Tilgen $\mathrm{M}$, Longère G, Anton-Lamprecht I. Ocular findings in progressive erythrokeratodermia. Ger J Ophthalmol 1993;2; 368.

110. Hughes WR Jr. Alkali burns of the eye. I. Review of the literature and summary of present knowledge. Arch Ophthalmol 1946;35;423.

111. Hughes WR JR. Alkali burns of the eye. II. Clinical and pathologic course. Arch Ophthalmol 1946;36;189.

112. Roper-Hall MJ. Thermal and chemical burns. Trans Ophthalmol Soc UK 1965:85;631.

113. Thoft RA. Chemical and thermal injury. Int Ophthalmol Clin 1979;19;243.
114. Brown SI, Wassermann HE, Dunn MW. Alkali burns of the cornea. Arch Ophthalmol 1969;82;91.

115. Duke-Elder S. System of ophthalmology. Vol. XIV, part 2. St Louis; Mosby, 1972:1011.

116. Matsua H, Smelser GK. Epithelium and stroma in alkaliburned corneas. Arch Ophthalmol 1973:89;396.

117. Faulkner WJ, Kenyon KR, Rowsey JJ, Hanninen L, Gipson IK, Gayler J. Chemical burns of the human ocular surface; clinicopathological studies in 14 cases. Invest Ophthalmol Vis Sci 1981;20(Suppl);8.

118. Schecter DR, Emery JM. Soper JW. Corneal neovascularization in therapeutic soft lens wear. Contact Intraocul Lens Med J 1975;1;141.

119. Weinberg RI. Deep corneal vascularization caused by aphakic soft contact lens wear. Am J Ophthalmol 1977;83; 121.

120. Clinch TE, Goins KM. Cobo LM. Treatment of contact lens-related ocular surface disorders with autologous conjunctival transplantation. Ophthalmology 1992:99:634

121. Copeland RR Jr, Char DH. Limbal autograft reconstruction after conjunctival squamous cell carcinoma. Am J Ophthalmol 1990;110:412.

122. Brown SI, Tragkis MP, Pearce DB. Corneal transplantation of severe alkali burns. Trans Am Acad Ophthalmol Otolaryngol 1972;76;1266.

123. Brown SI, Bloomfield SE, Pearce DB. Follow-up report on transplantation of the alkali burned cornea. Am J Ophthalmol 1974; $77 ; 538$.

124. Abel R Jr, Binder PS, Pilack FM, Kaufman HE. The results of penetrating keratoplasty after chemical burns. Trans Am Acad Ophthalmol Otolaryngol 1975:79;584

125. Kramer SG. Late numerical grading of alkali burns to determine keratoplasty prognosis. Trans Am Ophthalmol Soc 1983:81;97.

126. Kruse FE, Koch JM, Klein U, Rohrschneider K, Völcker HE, Waubke TN. The importance of limbal stem cells for the therapy of chemical burns. Ger J Ophthalmol 1993;2; 289.

127. Lemp MA. The surface of the corneal graft; in vivo colour specular microscopic study in the human. Trans Am Ophthalmol Soc 1989;87;619.

128. Mashima Y, Yamada M, Yamada H, Tsunoda K, Arimoto H. Limbal autograft transplantations for chronic ocular surface failures. Jpn J Clin Ophthalmol 1993:47:607.

129. Weise RA, Mannis MJ. Vastine DW, Fujikawa LS, Roth AM. Conjunctival transplantation; autologous and homologous grafts. Arch Ophthalmol 1985;103;1736.

130. Tseng SCG, Chen JJY, Huang AJW, Kruse FE, Tsai RJ. Classification of conjunctival surgeries for corneal diseases based on stem cell concept. Ophthalmol Clin North Am 1990:3;595.

131. Sundmacher R, Reinhard T, Heering P. Six years' experience with systemic cyclosporin A prophylaxis in high-risk perforating keratoplasty patients; a retrospective study. Ger J Ophthalmol 1992:1;432.

132. Pfau B, Kruse FE, Klein U, Zorn M, Rohrschneider K, Völcker HE. Comparison between local and systemic cyclosporin A concerning the concentration in anterior chamber and conjunctiva. Ger J Ophthalmol 1993;2;272.

133. Kruse FE, Rohrschneider K, Völcker HE. Limbal allografts [case report]. Ger J Ophthalmol 1993;2;376. 